\title{
High Molecular Weight Kininogen Is an Inhibitor of Platelet Calpain
}

\author{
Alvin H. Schmaier, Harlan Bradford, Lee D. Silver, Anthony Farber, Cheryl F. Scott, Darlene Schutsky, \\ and Robert W. Colman \\ Department of Medicine, Hematology/Oncology Section, and Thrombosis Research Center, Temple University School of Medicine, \\ Philadelphia, Pennsylvania 19140
}

\begin{abstract}
Recent studies from our laboratory indicate that a high concentration of platelet-derived calcium-activated cysteine protease (calpain) can cleave high molecular weight kininogen (HMWK). On immunodiffusion and immunoblot, antiserum directed to the heavy chain of HMWK showed immunochemical identity with alpha-cysteine protease inhibitor-a major plasma inhibitor of tissue calpains. Studies were then initiated to determine whether purified or plasma HMWK was also an inhibitor of platelet calpain. Purified alpha-cysteine protease inhibitor, alpha-2-macroglobulin, as well as purified heavy chain of HMWK or HMWK itself inhibited purified platelet calpain. Kinetic analysis revealed that HMWK inhibited platelet calpain noncompetitively $\left(K_{i} \simeq 5\right.$ nM). Incubation of platelet calpain with HMWK, alpha-2-macroglobulin, purified heavy chain of HMWK, or purified alphacysteine protease inhibitor under similar conditions resulted in an $\mathrm{IC}_{50}$ of 36, 500, 700, and $1,700 \mathrm{nM}$, respectively. The contribution of these proteins in plasma towards the inhibition of platelet calpain was investigated next. Normal plasma contained a protein that conferred a five to sixfold greater $\mathrm{IC}_{50}$ of purified platelet calpain than plasma deficient in either HMWK or total kininogen. Reconstitution of total kininogen deficient plasma with purified HMWK to normal levels $(0.67 \mu \mathrm{M})$ completely corrected the subnormal inhibitory activity. However, reconstitution of HMWK deficient plasma to normal levels of low molecular weight kininogen $(2.4 \mu \mathrm{M})$ did not fully correct the subnormal calpain inhibitory capacity of this plasma. These studies indicate that HMWK is a potent inhibitor as well as a substrate of platelet calpain and that the plasma and cellular kininogens may function as regulators of cytosolic, calcium-activated cysteine proteases.
\end{abstract}

\section{Introduction}

The neutral calcium-activated cysteine proteases (calpains) are a group of cytosolic enzymes, distributed in many cells $(1,2)$, whose specific intracellular functions are not known. Recent studies indicate that these proteases are contained within platelets (3-6), and that they cleave the high molecular weight hemostatic cofactors, von Willebrand factor (7), fibrinogen (8), and factor $\mathrm{V}$ (9). Studies from our laboratory indicate that a platelet calcium-activated cysteine protease increases the surface-mediated activity of high molecular weight kininogen (HMWK) ${ }^{1}$ as mea-

Received for publication 24 July 1985 and in revised form 19 December 1985.

1. Abbreviations used in this paper: DTT, dithiothreitol; HMWK, high molecular kininogen; LMWK, light molecular weight kininogen; PAGE, polyacrylamide gel electrophoresis.

J. Clin. Invest.

(c) The American Society for Clinical Investigation, Inc.

0021-9738/86/05/1565/09 \$1.00

Volume 77, May 1986, 1565-1573 sured by coagulant assay (10). Furthermore, when nanomolar concentrations of ${ }^{125} \mathrm{I}-\mathrm{HMWK}(120 \mathrm{kD})$ are incubated with platelet cytosol in the presence of $\mathrm{Ca}^{++}$, the radiolabeled protein is proteolyzed into a $100-\mathrm{kD}$ band as well as other cleavage products of smaller mass (10).

Recent studies suggest that the interaction of HMWK with tissue calpains may be more complex than simply serving as an additional substrate for platelet calpains. Studies by Ohkubo et al. (11) indicate that alpha-cysteine proteinase inhibitor-a major plasma protease inhibitor of cysteine proteases (12)-is identical in its amino acid sequence and immunochemical reactivity to plasma low molecular weight kininogen (LMWK). Moreover, Muller-Esterl et al. (13) and Sueyoshi et al. (14) have shown that kininogens functionally inhibit the cysteine proteases, papain and cathepsins $B, G, H$, and $L$. Because the synthesis of the plasma kininogens is controlled by one gene (15) and the heavy chain of HMWK is identical to the heavy chain of LMWK, both proteins should serve as inhibitors of cysteine proteases. Because the kininogens are inhibitors of papain and cathepsins (10), we hypothesized that both HMWK and LMWK could also be inhibitors of the calcium-requiring cysteine proteinases, the tissue calpains.

Alpha-cysteine protease inhibitor (LMWK) exists in plasma at a concentration of $2.4 \mu \mathrm{M}$ (16). Alpha-2-macroglobulin, which has a plasma concentration of $3.5 \mu \mathrm{M}$ (17), has also been described as an inhibitor of tissue calpains (1). In that HMWK has a plasma concentration of only $0.67 \mu \mathrm{M}(18)$, its affinity for the calpains would have to be much greater than either LMWK or alpha-2-macroglobulin in order for it to serve as an important calpain inhibitor. Studies were initiated to determine the efficiency of HMWK as an inhibitor of platelet calpain and to determine its relative reactivity in both purified systems and plasma, as compared to alpha-cysteine protease inhibitor (LMWK) and alpha-2-macroglobulin. In this report, we present evidence that HMWK in plasma is a potent inhibitor of platelet calpain and that a new biological function for kininogens must be considered.

\section{Methods}

Materials. ${ }^{14} \mathrm{C}$-methylated alpha-casein $(0.82 \mu \mathrm{Ci} / \mathrm{mg})$ and $\mathrm{Na}{ }^{125} \mathrm{I}(50$ $\mathrm{mCi} / \mathrm{mmol}$ ) were obtained from New England Nuclear, Boston, MA. Iodogen (Chloroamide, 1,3,4,6-tetrachloro-3alpha-6alpha-diphenylglycoluril was obtained from Pierce Chemical Co., Rockford, IL. Nitrocellulose paper, high and low molecular weight standards for polyacrylamide gel electrophoresis (PAGE) in sodium dodecyl sulfate (SDS), and dithiothreitol (DTT) were purchased from Bio-Rad Corp., Richmond, CA. Polyethylene glycol $(8,000)$ and kaolin were obtained from Fisher Scientific Co., King of Prussia, PA. Inosithin was purchased from Associated Concentrates, Woodside, NY. Sodium barbital buffer, pH 8.8, was purchased from Gelman Sciences, Inc., Ann Arbor, MI. Agarose (low electroendosmotic grade) was obtained from Marine Colloids, Inc., Rockland, ME. Rabbit anti-goat $\mathrm{F}(\mathrm{ab})_{2}^{\prime}$ affinity-purified antibody adsorbed with normal human serum was purchased from Pel-Freez, Rogers, AR. Alphacasein was purchased from Worthington Biochemical Corp., Freehold, NJ. Ultrogel AcA 34 was purchased from LKB Instruments, Rockville, 
MD. E-64 $N$-[ $N$-(L3-trans-carboxyoxirane-2-carbonyl)-L-leucyl] agmatine was purchased from Enzyme System Products, Livermore, CA. All other reagents were obtained from Sigma Chemical Co., St. Louis, MO, and were of the best reagent grade.

Plasmas and platelets. Pooled normal plasma (lot N10) was purchased from George King Biomedicals, Inc., Overland Park, KS. Total kininogendeficient plasma (Williams plasma), i.e., plasma lacking in both HMWK and LMWK was donated by Mrs. M. Williams, Philadelphia, PA (19). HMWK-deficient plasma (19) (Fitzgerald plasma) was a generous gift of Dr. A. Scicli, Henry Ford Hospital, Detroit, MI. The value for total kininogen antigen was determined by electroimmunodiffusion (18) for the normal plasma and Fitzgerald plasma used in these studies and was found to be $352 \mu \mathrm{g} / \mathrm{ml}(4.92 \mu \mathrm{M})$ and $63 \mu \mathrm{g} / \mathrm{ml}(0.98 \mu \mathrm{M})$, respectively. Outdated $(>72 \mathrm{~h})$ normal platelet concentrates were donated by the PennJersey Regional Red Cross, Philadelphia, PA.

Preparation of fresh platelet cytosol. $450 \mathrm{ml}$ of fresh blood from one donor was collected into $73 \mathrm{mM}$ citric acid, $3 \mathrm{mM}$ trisodium citrate containing $2 \%$ dextrose (1:10) (ACD), from which platelet-rich plasma was obtained (20). After adjusting the $\mathrm{pH}$ to 6.5 with acid-citrate-dextrose, the platelet-rich plasma was washed twice by the centrifugation technique of Mustard et al. (21). The Tyrode's buffer, containing $\mathrm{Ca}^{++}(2 \mathrm{mM})$ and $\mathrm{Mg}^{++}(1 \mathrm{mM})$, had both apyrase and heparin $(12.5 \mathrm{U} / \mathrm{ml})$ in the first wash, and apyrase alone in the second wash. Apryase was prepared from potatoes by the method of Molnar and Lorand (22) and was titered so that only a minimal amount was used (prevention of second-wave platelet aggregation by ADP). The final washed pellet was resuspended in 1-2 $\mathrm{ml}$ of Hepes buffer (23) without bovine serum albumin and dextrose or $0.1 \mathrm{M}$ Tris-Cl, $0.15 \mathrm{M} \mathrm{NaCl}, \mathrm{pH} 7.4$ (Tris-buffered saline) with or without $1 \mathrm{mM}$ EDTA. These platelet preparations contained $<0.05 \%$ red cells and $<0.03 \%$ leukocytes (monocytes, granulocytes, and lymphocytes, combined). After making the platelet suspension hypotonic by addition of $0.5-1 \mathrm{ml}$ of deionized water, the platelets were lysed by freezing (dry ice) and thawing $\left(37^{\circ} \mathrm{C}\right)$ four times. The supernatants of the lysed platelets were collected, after centrifugation at $12,000 \mathrm{~g}$ in an Eppendorf centrifuge (Brinkmann Instruments, Inc., Westbury, NY), and ultracentrifuged at 100,000 $\mathrm{g}$ (model L3-50, Beckman Instruments, Inc., Palo Alto, CA) for $90 \mathrm{~min}$ at $4^{\circ} \mathrm{C}$ to collect platelet cytosol. Cytosol of lysed fresh platelets was used fresh, or stored at $-70^{\circ} \mathrm{C}$ and used once after thawing. Assessment of cleavage of exogenous ${ }^{125} \mathrm{I}-\mathrm{HMWK}$ by enzymes in platelet cytosol was performed on aliquots of the cytosol- ${ }^{125}$ IHMWK mixture $(25-50 \mu \mathrm{l})$ that were reduced by the addition of $2 \%$ $\beta$-mercaptoethanol at $100^{\circ} \mathrm{C}$ for $10 \mathrm{~min}$. The samples were run on $7.5 \%$ SDS-PAGE (24) followed by autoradiography of the dried gel. Quantification of the extent of ${ }^{125} \mathrm{I}-\mathrm{HMWK}$ cleavage was performed by densitometer scan of the autoradiograms using a SD3000 Spectrodensitometer (Schoeffel Instrument Division, Kratos, Inc., Westwood, NJ). The relative peak areas were quantified by weighing paper tracings of the peaks outlined by the recorder.

Functional assays. HMWK was assayed by one-stage kaolin-activated coagulant assay using total kininogen-deficient plasma as substrate, as previously reported (18). $1 \mathrm{U}$ was defined as that amount in $1 \mathrm{ml}$ of pooled normal plasma.

The calcium-activated cysteine protease (calpain) was measured by its ability to hydrolyze alpha-casein in a modified assay as described by Waxman and Krebs (25). The casein substrate was prepared such that its final concentration in the assay was $5 \mathrm{mg} / \mathrm{ml}$ in $0.05 \mathrm{M}$ Tris-Cl, pH 7.5 , containing $3 \mathrm{mM}$ DTT. An assay volume of $200 \mu$ l containing the above substrate and sample was used. $25 \mu$ l of enzyme sample to be measured was added at $0^{\circ}$ and then warmed to $25^{\circ} \mathrm{C}$ in a regulated water bath for 2-3 min. The hydrolysis reaction was started by adding $20 \mathrm{mM}$ $\mathrm{CaCl}_{2}$ (4 mM final concentration) and the samples were incubated for $60 \mathrm{~min}$ at $25^{\circ} \mathrm{C}$ with intermittent mixing. The addition of $20 \mathrm{mM}$ EDTA instead of $\mathrm{CaCl}_{2}$ served as a blank. The reaction was terminated by precipitation with $0.45 \mathrm{ml}$ of ice-cold $4 \%$ perchloric acid and the samples were mixed and kept on ice prior to centrifugation at 12,000 $\mathrm{g}$. The amount of alpha-casein hydrolysis was determined by the absorbance of the supernatant at $280 \mathrm{~nm}$, after its EDTA-blank had been subtracted. $1 \mathrm{U} / \mathrm{ml}$ of enzyme activity was arbitrarily defined as the amount of en- zyme that increased the absorbance at $280 \mathrm{~nm} 1.000 \mathrm{OD} / \mathrm{h} \cdot \mathrm{ml}$. The hydrolysis of unlabeled alpha-casein was used only to monitor the enzyme during the purification procedure.

A modified ${ }^{14} \mathrm{C}$-methylated alpha-casein radiometric assay (26) was employed to measure the effect of various substances on the calciumactivated cysteine protease. Enzyme at $25^{\circ} \mathrm{C}$ was added to a tube containing $0.05 \mathrm{M}$ Tris-Cl, pH 7.5, DTT (3 mM), EDTA (2 mM), and potential inhibitors prior to a precise 2-min incubation. The residual enzymatic activity was then monitored with the ${ }^{14} \mathrm{C}$-methylated alphacasein. The addition of the EDTA during the enzyme-inhibitor interaction greatly reduced the autoinactivation of calpain. In studies with E-64, EDTA was excluded from the incubation mixture of the enzyme with inhibitor, because free $\mathrm{Ca}^{++}$was essential to observe maximal inhibitory activity $(27,28)$. The radiometric assay was identical to the cold assay with the following exceptions: the assay of residual enzymatic activity included $5 \mathrm{mM} \mathrm{Ca}^{++}$; unlabeled alpha-casein was present at $1 \mathrm{mg} /$ $\mathrm{ml}$, and ${ }^{14} \mathrm{C}$-methylated alpha-casein $(20,000 \mathrm{dpm})$, which was $<1 \%$ of the total alpha-casein present, was included in the reaction tube. Background values for each incubation were obtained by substituting EDTA for calcium. After a 1-h incubation, the reaction and background samples were precipitated with perchloric acid ( $10 \%$ final concentration) in the presence of $1.25 \mathrm{~g} \%$ bovine serum albumin. After precipitation and centrifugation, the supernatants $(300-600 \mu \mathrm{l})$ were added to $10 \mathrm{ml}$ of scintillation fluid (Liquicent, National Diagnostics, Somerville, NJ). After the background counts were subtracted from the total activity for each point, the percent inhibition for each potential inhibitor was determined by the formula, 1 minus the ratio of the enzyme activity in the inhibitortreated sample to the enzyme activity in the absence of inhibitors multiplied by 100 .

In studies to determine the kinetic mechanism of HMWK inhibition of calpain, hydrolysis of the substrate by enzyme in the absence or presence of HMWK proceeded for $10 \mathrm{~min}$ before precipitation with perchloric acid. The $K_{\mathrm{i}}$ of HMWK inhibition of platelet calpain was determined by a secondary plot of the slope of the curve of the double-reciprocal plot at each inhibitor concentration versus inhibitor concentration and by a computer program (29) using a TRS-80 model 4P (Tandy Corporation, Fort Worth, TX).

Proteins. HMWK was purified by a modified procedure (10) of Kerbiriou and Griffin (30) which included $0.2 \mathrm{M}$ epsilon-aminocaproic acid in all buffers and $2 \mathrm{mM}$ diisopropylflurophosphate added to the pooled material prior to each step. This preparation of HMWK on reduced $8 \%$ SDS-PAGE (24) was mostly a single band of $120 \mathrm{kD}$ with $>98 \%$ purity and had a specific activity of 12-20 U/mg. Purified HMWK was radiolabeled with ${ }^{125}$ I using Iodogen, by a procedure previously reported (18).

The heavy $(64 \mathrm{kD})$ and intermediate light chain $(56 \mathrm{kD})$ of HMWK were purified by a modified procedure of Kerbiriou and Griffin (30). After a 16-h incubation of HMWK $(120 \mathrm{kD})$ with purified human urinary kallikrein (a generous gift by Dr. Harry Margulies, University of South Carolina, Charleston, SC), the cleaved HMWK was alkylated with 120 $\mathrm{mM}$ iodoacetamide followed by reduction with $50 \mathrm{mM}$ DTT. The sample was applied to a SP Sephadex column in $0.01 \mathrm{M}$ sodium acetate, 0.08 $\mathrm{M} \mathrm{NaCl}, \mathrm{pH}$ 5.4. The alkylated and reduced heavy chain of HMWK was not absorbed to the cation exchanger. The 56-kD light chain was eluted with a linear $\mathrm{NaCl}$ gradient from 0.08 to $0.5 \mathrm{M}$. The specific activity of the purified 56-kD light chain of HMWK was $7.8 \mathrm{U} / \mathrm{mg}$.

Purified alpha-cysteine protease inhibitor $(1 \mathrm{mg} / \mathrm{ml})$ was a generous gift of Drs. G. Salvesan and A. Barrett, Cambridge University, England. Purified $\mathrm{Cl}$ inhibitor, with a concentration of $1.02 \mathrm{mg} / \mathrm{ml}(9.7 \mu \mathrm{M})$ was prepared as previously reported (31). Purified alpha-1-antitrypsin (4 mg/ $\mathrm{ml}, 64.5 \mu \mathrm{M}$ ) was a generous gift of Dr. Charles Glaser, Pacific Medical Center, San Francisco, CA (32). Partially purified alpha-2-macroglobulin was a generous gift of Dr. Marc Schapira, Hôpital Cantonal, Geneva, Switzerland. As previously reported, this alpha-2-macroglobulin was $90 \%$ pure with a concentration of 1.43 antigen $\mathrm{U} / \mathrm{ml}(2.6 \mu \mathrm{M})(33)$. One antigen unit of alpha-2-macroglobulin is the amount of alpha-2-macroglobulin contained in $1 \mathrm{ml}$ of pooled normal plasma (lot N10, George King Biomedicals).

Purification of platelet calpain. Platelet calcium-activated cysteine 
protease (calpain) was purified from washed platelet concentrates suspended in $0.1 \mathrm{M}$ Tris-Cl pH 7.5 containing $5 \mathrm{mM}$ EDTA and $3 \mathrm{mM}$ DTT. After sonication twice at $0^{\circ}$ for $10 \mathrm{~s}$ on a Branson sonicator (Ultrasonics Inc., Plainview, NY), the lysate was ultracentrifuged at 100,000 $g$ (model L3-50, Beckman Instruments, Inc.) for $60 \mathrm{~min}$ at $4^{\circ}$. The cytosol was then precipitated with polyethylene glycol $(8,000)$, final concentration 3\%. The resulting supernatant was reprecipitated with polyethylene glycol, final concentration $20 \%$. The second pellet, resuspended in $0.05 \mathrm{M}$ Tris- $\mathrm{Cl}, 0.05 \mathrm{M} \mathrm{NaCl}, \mathrm{pH} 7.5$, containing $5 \mathrm{mM}$ EDTA, and $2 \mathrm{mM}$ DTT, was applied to a DE-52 ion exchange column $(2.6 \times 21$ $\mathrm{cm}$ ); the enzyme was eluted with a linear salt gradient from $0.05 \mathrm{M} \mathrm{NaCl}$ to $0.5 \mathrm{M} \mathrm{NaCl}$. Fractions containing the enzyme were concentrated by precipitation with $20 \%$ polyethylene glycol and resuspended in $0.05 \mathrm{M}$ Tris- $\mathrm{Cl}, 0.5 \mathrm{M} \mathrm{NaCl}$, containing $5 \mathrm{mM}$ EDTA and $2 \mathrm{mM}$ DTT prior to application on a reactive red agarose 120 column $(0.8 \times 40 \mathrm{~cm})$. The enzyme was eluted with $0.05 \mathrm{M}$ Tris- $\mathrm{Cl}$, pH 7.5, containing $5 \mathrm{mM}$ EDTA and $2 \mathrm{mM}$ DTT. The final step of purification was gel filtration on a Ultrogel AcA $34(55 \times 0.8 \mathrm{~cm})$ column in the same buffer (34).

The purified protein was analyzed on reduced SDS-PAGE (19) and on nondenaturing PAGE (35). The calcium concentrations at a given pH used for activation of purified platelet calpain were determined by having EDTA in the suspension buffer. Known quantities of calcium were added and the free calcium concentration was calculated by a computer program $(36,37)$ on a TRS-80 Model III (Tandy Corporation, Fort Worth, TX), using all known equilibrium constants for all of the

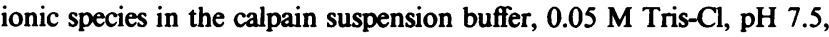
containing $4 \mathrm{mM}$ EDTA and $10 \mathrm{mM} \mathrm{MgCl}$.

Protein assays were performed by the methods of Bradford (38), Lowry et al. (39), and Ross and Schatz (40) using crystalline bovine serum albumin as the standard.

Immunochemical assays. Goat antibody and antiserum directed to the light chain of HMWK (18) and to both the heavy and light chains of HMWK $(41)$ were prepared as previously reported $(18,41)$. Immunodiffusion in $1 \%$ agarose was performed as previously described (18, 41). The alpha-2-macroglobulin concentration of normal plasma, Fitzgerald plasma, and Williams plasma was determined by radial immunodiffusion $(31,33)$.

Immunoblots were performed by a modified technique of Towbin et al. (42). Samples for electroblotting, nonreduced or reduced with $2 \%$ $\beta$-mercaptoethanol, were run on an $8 \%$ SDS-PAGE, and the protein was subsequently transferred to nitrocellulose by electroblotting for $16 \mathrm{~h}$ at $4^{\circ} \mathrm{C}$ at $40 \mathrm{~V}$ using a running buffer of $25 \mathrm{mM}$ Tris- $\mathrm{Cl}, 192 \mathrm{mM}$ glycine, pH 8.3, containing $20 \%$ methanol. After electroblotting, the nitrocellulose was incubated with $4 \%$ radioimmunoassay grade bovine serum albumin in $0.01 \mathrm{M}$ Tris-Cl, $0.15 \mathrm{M} \mathrm{NaCl}, \mathrm{pH} 7.5$, containing $1 \mathrm{mM}$ EDTA on a rotating shaker at $23^{\circ} \mathrm{C}$ for $1 \mathrm{~h}$. At the end of the hour, the bovine serum albumin solution was made $0.05 \%$ by the addition of Tween-20. After a 5-min incubation, anti-HMWK (18) or anti-total kininogen antibody (41) (i.e., antibody that recognizes both HMWK and LMWK) or antiserum was added to the bovine serum albumin solution with Tween-20 and incubated for $2 \mathrm{~h}$ on a rotating shaker at $23^{\circ} \mathrm{C}$. After incubation, the paper was washed four times with $0.01 \mathrm{M}$ Tris-Cl, $0.15 \mathrm{M} \mathrm{NaCl}, \mathrm{pH}$ 7.5 , containing $0.05 \%$ Tween-20. An affinity-purified ${ }^{125} \mathrm{I}$-rabbit antigoat antibody in the same buffer was incubated with the nitrocellulose paper on a rotating shaker for $2 \mathrm{~h}$ at $23^{\circ} \mathrm{C}$. The rabbit anti-goat antibody was radiolabeled with ${ }^{125}$ I using lodogen by a technique previously reported for radiolabeling HMWK (18). After this, the nitrocellulose paper was washed four times in the same buffer containing $0.2 \%$ bovine serum albumin followed by two washes containing buffer without albumin. The nitrocellulose was stained with $0.1 \%$ amidoblack in $45 \%$ methanol and $7 \%$ acetic acid. After drying, autoradiography of the dried nitrocellulose was performed.

\section{Results}

Inhibition of cleavage of ${ }^{125} I-H M W K$ by calpain in platelet cytosol by excess unlabeled HMWK. Platelet cytosol from $3.1 \times 10^{9}$ platelets/ml not pretreated with inhibitors produced proteolysis
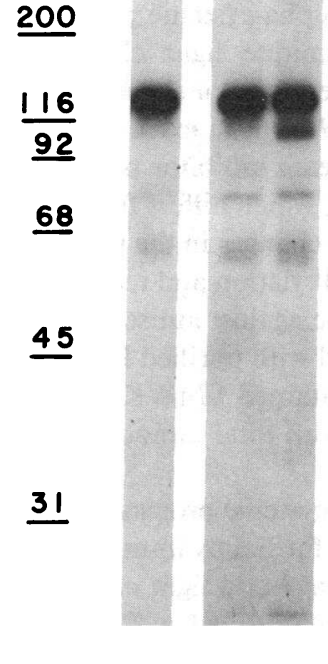

LE HC HA

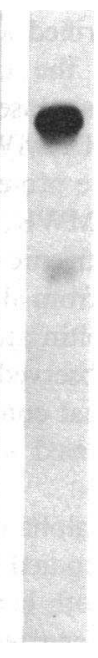

CN
Figure 1. Inhibition of cleavage of ${ }^{125}$ I-HMWK by calpain in platelet cytosol by unlabeled HMWK. A mixture of platelet cytosol (8.5 vol) from lysed platelets $\left(3.1 \times 10^{9}\right.$ platelets $\left./ \mathrm{ml}\right)$ and 1.5 vol of $0.1 \mathrm{M}$ Tris- $\mathrm{HCl}, 0.15$ $\mathrm{M} \mathrm{NaCl}, \mathrm{pH} 7.4$, was incubated for $10 \mathrm{~min}$ at $37^{\circ} \mathrm{C}$ in the presence of $0.5 \mathrm{mM}$ leupeptin $(L E)$ or $2 \mu \mathrm{M}$ unlabeled HMWK $(H C)$, or left untreated $(H A)$. At the end of the incubation, 7.5 nM of ${ }^{125}$ I-HMWK was introduced into each aliquot $(L E$, $H C, H A)$. After incubation for 1 $\mathrm{h}$ at $37^{\circ} \mathrm{C}$, the reaction was stopped by the introduction of $4 \%$ SDS containing $2 \% \beta$-mercaptoethanol and boiled for 10 min. Lane $C N$ is a control incubation of ${ }^{125} \mathrm{I}-\mathrm{HMWK}$ introduced into buffer. $25 \mu \mathrm{l}$ from each sample was applied to an 8\% SDS-PAGE for electrophoresis. After drying, autoradiography was performed for 24-60 h. The numbers to the left represent molecular weight standards in kilodaltons.

of the ${ }^{125} \mathrm{I}-\mathrm{HMWK}(7.5 \mathrm{nM})$ with the appearance of bands at 100 and $75 \mathrm{kD}$ (Fig. 1). Densitometer scan of a submaximally exposed autoradiogram revealed that $33 \%$ of the ${ }^{125} \mathrm{I}-\mathrm{HMWK}$ was cleaved in the untreated platelet cytosol as compared with $6 \%$ cleaved ${ }^{125} \mathrm{I}-\mathrm{HMWK}$ in the control incubation mixture. The majority of the cleaved ${ }^{125} \mathrm{I}-\mathrm{HMWK}$ was in a distinct $100-\mathrm{kD}$ band. However, when the platelet material was pretreated with either leupeptin $(0.5 \mathrm{mM})$ or unlabeled HMWK $(2 \mu \mathrm{M})$, the $100-\mathrm{kD}$ band from ${ }^{125} \mathrm{I}-\mathrm{HMWK}$ was not seen although the 75kD band was still present. The leupeptin-treated platelet cytosol had $6 \%$ cleaved ${ }^{125} \mathrm{I}-\mathrm{HMWK}$, similar to the control; the unlabeled HMWK-treated platelet cytosol had $12 \%$ cleaved ${ }^{125}$ I-HMWK. This latter finding suggested that in addition to being a substrate for platelet calpain, HMWK may also be an inhibitor.

Immunochemical identity of alpha-cysteine protease inhibitor with plasma kininogens. Using antiserum directed against total kininogen (both HMWK and LMWK), purified alpha-cysteine protease inhibitor produced a precipitin arc that showed identity with HMWK (Fig. 2). However, HMWK showed an additional

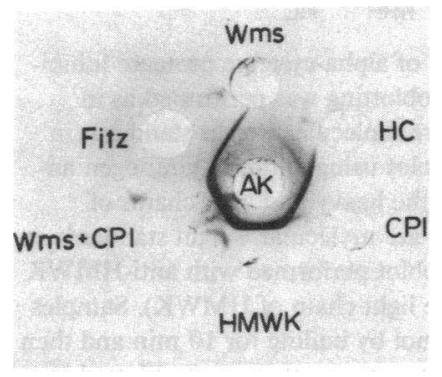

Figure 2. Immunodiffusion with antikininogen antisera. Plasma or purified proteins were added to wells (10-20 $\mu \mathrm{l} /$ well) in $1 \%$ agarose gel in sodium barbital buffer, $\mathrm{pH} 8.8, \tau$ / $2=0.0375$. Immunodiffusion was allowed for $24 \mathrm{~h}$ at $23^{\circ} \mathrm{C}$. After $48 \mathrm{~h}$ of soaking in $0.01 \mathrm{M}$ sodium phosphate, $0.15 \mathrm{M}$ $\mathrm{NaCl}, \mathrm{pH} 7.4$, the plate was dried and stained with 0.5\% Coomassie brillant blue R-250 and $1.0 \%$ amidoblack in methanol-acetic acid $\mathrm{H}_{2} \mathrm{O}$ (5:5:1). $A K, 10 \mu$ of antikininogen antiserum; $W \mathrm{~ms}, 10 \mu \mathrm{l}$ of total kininogen-deficient plasma (Williams plasma); $H C$, purified heavy chain of HMWK; CPI, $10 \mu \mathrm{g}$ of purified alpha-cysteine protease inhibitor, $H M W K, 25 \mu \mathrm{g}$ of purified HMWK; Wms $+C P I, 10 \mu$ l of total kininogen-deficient plasma and $10 \mu \mathrm{g}$ of purified alpha-cysteine protease inhibitor, Fitz, $10 \mu \mathrm{l}$ of HMWK-deficient plasma (Fitzgerald plasma). 
spur of partial identity to the purified alpha-cysteine protease inhibitor, probably representing the unique light chain of HMWK. In turn, alpha-cysteine protease inhibitor showed partial identity to the heavy chain of HMWK. The extra spur of partial identity with alpha-cysteine protease inhibitor probably resulted from the light chain of LMWK, which differs from the light chain of HMWK, and/or antigenic changes in the purified heavy chain of HMWK resulting from alkylation and reduction in its preparation. A single precipitin arc against antiserum directed to plasma kininogen was observed with purified HMWK and Fitzgerald plasma (plasma that contained LMWK but no HMWK). No precipitin arc occurred with total kininogen-deficient plasma.

The immunoidentification of alpha-cysteine protease inhibitor with plasma kininogens was studied further by immunoblot (Fig. 3). Antiserum directed to both heavy and light chains of HMWK (anti-kininogen $A b$ ) recognized purified and plasma HMWK (120 kD) as well as purified light chain of HMWK (56 $\mathrm{kD}$ ) and purified alkylated and reduced heavy chain of HMWK $(64 \mathrm{kD})$ (Fig. 3 left). Likewise, this antiserum recognized purified alpha-cysteine protease inhibitor which gave a broad band between 60 and $65 \mathrm{kD}$. Because there was some overlap of the band of alpha-cysteine protease inhibitor on this gel electrophoresis system with the purified 56-kD light chain of HMWK, studies were performed to determine if the light chain of HMWK contaminated the alpha-cysteine protease inhibitor preparation. Because the light chain accounts for all of the coagulant activity, the finding that this preparation of alpha-cysteine protease inhibitor had $<0.01 \mathrm{U} / \mathrm{ml}$ coagulant activity indicated that the

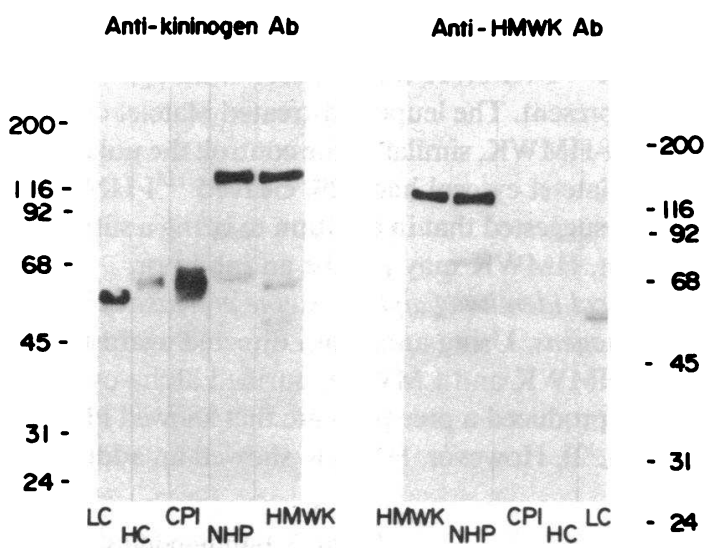

Figure 3. Immunoblot identification of alpha-cysteine protease inhibitor with plasma kininogens. Immunoblotting was performed as in Methods. The numbers on the left are molecular weight standards in kilodaltons referring to the immunoblot using antitotal kininogen antiserum (antiserum directed to both the heavy and light chains of HMWK). The numbers on the right are molecular weight standards in kilodaltons that refer to the immunoblot performed with anti-HMWK antiserum (antiserum directed to the light chain of HMWK). Samples were reduced in $2 \% \beta$-mercaptoethanol by boiling for $10 \mathrm{~min}$ and then run on $8 \%$ SDS-PAGE. Protein on the gel was then electroblotted to nitrocellulose (see Methods). Immunoidentification was performed on nitrocellulose paper. $H M W K, 0.25 \mu \mathrm{g}$ of purified HMWK added to gel; $N H P, 1 \mu l$ of normal human plasma; $C P I, 1 \mu \mathrm{g}$ of purified alphacysteine protease inhibitor, $H C, 0.23 \mu \mathrm{g}$ of reduced and alkylated purified heavy chain of HMWK; $L C, 0.20 \mu \mathrm{g}$ of purified $56-\mathrm{kD}$ light chain of HMWK. After the immunoblot, the dried nitrocellulose paper was exposed to $x$-ray paper for autoradiography for $\geq 60 \mathrm{~h}$. The present gel is one representative experiment of two.
Table I. Purification of Platelet Calpain

\begin{tabular}{|c|c|c|c|c|c|}
\hline & $\begin{array}{l}\text { Total } \\
\text { activity }\end{array}$ & $\begin{array}{l}\text { Total } \\
\text { protein }\end{array}$ & $\begin{array}{l}\text { Specific } \\
\text { activity }\end{array}$ & $\begin{array}{l}\text { Purifi- } \\
\text { cation }\end{array}$ & Recovery \\
\hline & $U$ & $m g$ & $U / m g$ & & \% \\
\hline Sonicated washed platelets & 1,500 & 2,338 & 0.64 & 1 & 100 \\
\hline $100,000 \mathrm{~g}$ supernatant & $1,497^{*}$ & 1,271 & $1.18^{*}$ & 1.8 & 99 \\
\hline 3\% PEG $\ddagger$ supernatant & 1,346 & 990 & 1.36 & 2.1 & 90 \\
\hline 20\% PEG $\ddagger$ resuspension & 594 & 301 & 1.97 & 3.1 & 40 \\
\hline DE-52 & 580 & 62 & 9.35 & 14.6 & 39 \\
\hline Reactive red agarose & 301 & 11.3 & 26.5 & 41.4 & 20 \\
\hline Ultrogel AcA 34 & 293 & 4.8 & 60.0 & 94 & 19.5 \\
\hline
\end{tabular}

* The activity and specific activity in this fraction is uncorrected for the possible presence of the endogenous inhibitor, calpastatin (2). $\ddagger$ PEG, polyethylene glycol 8000 .

HMWK light chain was not present. The absence of the light chain of HMWK in the alpha-cysteine protease inhibitor preparation was confirmed by further immunoblot studies with antiserum uniquely directed to the light chain of HMWK (Fig. 3 right). Antiserum directed to the light chain of HMWK recognized purified HMWK, HMWK in normal plasma, and purified 56-kD light chain of HMWK. The purified heavy chains from either HMWK or alpha-cysteine protease inhibitor were not recognized by antiserum directed to the light chain of HMWK. These combined immunoblot studies indicated that purified alpha-cysteine protease inhibitor was immunochemically similar to the common heavy chain of HMWK and LMWK.

Purification of platelet calpain. Human platelet calpain was purified from platelet concentrates 94-fold with a final yield of $19.5 \%$ (Table I). The exact degree of purification was difficult to assess in that an inhibitor, calpastatin, (2) is present in the sonicate. The specific activity of the enzyme was $60 \mathrm{U} / \mathrm{mg}$. On nondenaturing $10 \%$ PAGE without SDS, this purified protein was $90 \%$ pure, as determined by densitometric scan of the stained gel (Fig. 4). On a $10 \%$ SDS-PAGE, $75 \%$ of the protein on densitometric gel scan was associated with a major band 80 at $\mathrm{kD}$ and a minor band at $30 \mathrm{kD}$ (Fig. 4). Minor bands ( $<25 \%$ of the protein) were recognized at $140-160 \mathrm{kD}$. Both the 80 - and 30 -

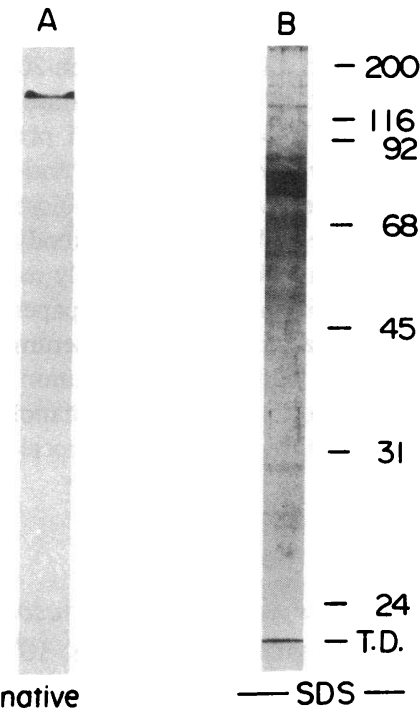

Figure 4. Gel electrophoresis of purified platelet calpain. $(A) 10$ $\mu \mathrm{g}$ of purified platelet calpain was applied to a $10 \%$ alkaline PAGE (native) and electrophoresed at $25 \mathrm{~mA}$ for $5 \mathrm{~h}$ at $4^{\circ} \mathrm{C}$. (B) $10 \mu \mathrm{g}$ of purified platelet calpain, after reduction with $2 \% \beta$-mercaptoethanol and boiling for $10 \mathrm{~min}$, was subjected to $10 \%$ SDS-PAGE (SDS) and electrophoresed at $30 \mathrm{~mA}$ for $4 \mathrm{~h}$ at $23^{\circ} \mathrm{C}$. Both gels were stained with Coomassie blue. The numbers to the right of the gel represent molecular weight standards in kilodaltons. 
$\mathrm{kD}$ bands comigrated with the fractions containing the protease activity on the gel filtration column.

Characterization of platelet calpain. The calcium dependence of the purified calpain was evaluated over a range of 10-1,300 $\mu \mathrm{M}$ free calcium (Fig. 5). The $\mathrm{EC}_{50}$ was $150 \mu \mathrm{M}$ free $\mathrm{Ca}^{++}$and activation was negligible below $100 \mu \mathrm{M}$ (Fig. 5). Activation of the enzyme was maximal at $500 \mu \mathrm{M}$ free calcium. The finding that the purified platelet calpain had the greatest activity at $\sim 500$ $\mu \mathbf{M}$ free calcium indicated that platelet calpain was a calpain II (2). In this study, magnesium was used to prevent a pH change owing to the liberation of $\mathrm{H}^{+}$from EDTA as calcium was added. However, when $\mathrm{Mg}^{++}$was omitted, the $\mathrm{pH}$ changed only 0.15 $\mathrm{U}$ and the $\mathrm{EC}_{50}$ for $\mathrm{Ca}^{++}$was similar.

Studies with inhibitors were performed to further characterize the enzyme as a calcium-activated cysteine protease (Table II). Both EDTA and EGTA, individually, at $0.55 \mathrm{mM}$ completely neutralized the enzymatic activity, further indicating that it was specifically calcium-dependent. Sulfhydryl blocking agents, $\mathrm{HgCl}_{2}(3 \mathrm{mM})$ and iodoacetamide $(1 \mathrm{mM})$, as well as bacterial protease inhibitors, leupeptin $(10 \mathrm{mM})$ and antipain $(33 \mu \mathrm{M})$, were excellent inhibitors. In the presence of $0.88 \mathrm{mM}$ free $\mathrm{Ca}^{++}$, $0.80 \mu \mathrm{M}$ E-64, an active site directed inhibitor, inactivated $96 \%$ of the enzyme's activity in $20 \mathrm{~min}$. These investigations indicated that the enzyme had a free thiol group exposed by $\mathrm{Ca}^{++}$, essential for its activity, similar to the requirement noted previously (27, 28). In contrast, little inhibition was found by the serine protease inhibitors, benzamidine (10 $\mathrm{mM})$, phenylmethylsulfonylfluoride (1 $\mathrm{mM})$, aprotinin $(0.15 \mathrm{mM})$, and diisopropylfluorphosphate $(5 \mathrm{mM})$. These studies support the conclusion in Fig. 5 that the enzyme is a calpain II.

Inhibition of platelet calpain by purified plasma proteins. The effect of various plasma proteins on the activity of platelet calpain was investigated (Table III). Purified plasma proteins, at a final concentration of $200 \mathrm{nM}$ were incubated with platelet calpain. Alpha-cysteine protease inhibitor, as well as purified heavy chain of HMWK, inhibited platelet calpain $11 \%$ and $23 \%$, respectively. Purified alpha-2-macroglobulin inhibited $29 \%$ of the platelet calpain activity whereas purified $\mathrm{Cl}$ inhibitor (214 $\mathrm{nM})$, alpha-1-antitrypsin (3,200 nM), and purified 56-kD light chain of HMWK produced little inhibition. However, HMWK

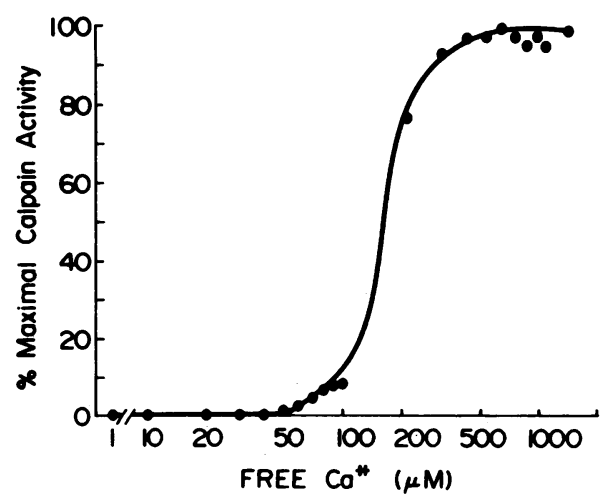

Figure 5. Calcium activation curve for platelet calpain. Purified platelet calpain was activated by the addition of increasing concentrations of free calcium from 10 to $1,300 \mu \mathrm{M}$ in $0.05 \mathrm{M}$ Tris-Cl, $\mathrm{pH} 7.5$, containing $4 \mathrm{mM}$ EDTA and $10 \mathrm{mM} \mathrm{MgCl}$. Using the known equilibrium constants for each of the ionic species in this buffer at this $\mathrm{pH}$ (34), the concentration of the free calcium needed to activate the enzyme was calculated by a computer program (35).
Table II. Inhibition of Platelet Calpain

\begin{tabular}{lc}
\hline Inhibitor & \% inhibition \\
\hline EDTA $(0.55 \mathrm{mM}) \ddagger$ & 100 \\
EGTA $(0.55 \mathrm{mM}) \ddagger$ & 100 \\
Leupeptin $(10 \mu \mathrm{M})$ & 96 \\
Leupeptin $(1 \mu \mathrm{M})$ & 68 \\
HgCl $(3 \mathrm{mM})$ & 100 \\
lodoacetamide $(1 \mathrm{mM})$ & 91 \\
Antipain $(33 \mu \mathrm{M})$ & 83 \\
Phenylmethylsulfonyl Fluoride $(1 \mathrm{mM})$ & 16 \\
Benzamidine $(10 \mathrm{mM})$ & 23 \\
Aprotinin $(0.15 \mathrm{mM}) \S$ & 0 \\
Diisopropylflurophosphate $(5 \mathrm{mM}) \S$ & 0 \\
\end{tabular}

* Each inhibitor, at the concentration indicated in parenthesis, was incubated for $2 \mathrm{~min}$ with the purified platelet calpain at room temperature prior to assay in the presence of 2 mM EDTA.

¥ Values represent excess chelator (mM) after the enzyme was stabilized to prevent loss of activity during the 2-min incubation.

$\S$ The inhibitor was preincubated for $10 \mathrm{~min}$ with the purified platelet calpain at $25^{\circ} \mathrm{C}$.

produced $93 \%$ inhibition of the enzyme activity. This latter finding suggested that HMWK, as well as alpha-cysteine protease inhibitor (LMWK) and alpha-2-macroglobulin, were plasma inhibitors of platelet calpain. Purified HMWK was a true inhibitor of platelet calpain. The presence of HMWK noncompetitively inhibited platelet calpain with an apparent $K_{\mathrm{i}}$ of $5.15 \mathrm{nM} \pm 0.61$ (mean \pm SEM) (data not shown) as analyzed from a double-reciprocal Lineweaver-Burk plot.

Further studies were performed with purified proteins in order to approximate their relative inhibitory potency of platelet calpain (Fig. 6). HMWK, at 50\% normal plasma concentration (333 nM), inhibited $95 \%$ of the enzyme activity whereas alpha2-macroglobulin, at $50 \%$ normal plasma concentration $(1.7 \mu \mathrm{M})$, and alpha-cysteine protease inhibitor, at normal plasma concentration $(2.4 \mu \mathrm{M})$, only inhibited $72 \%$ and $58 \%$, respectively, of the platelet calpain activity. Under these conditions, the $\mathrm{IC}_{50}$ of HMWK for platelet calpain was $36 \mathrm{nM}$. Unlike some calpain inhibitors which react with the free sulfhydryl group at the enzyme active site $(27,28)$, the ability of HMWK, at any concentration, to inhibit platelet calpain was not influenced by the

Table III. Inhibition of Platelet Calpain by Purified Plasma Proteins

\begin{tabular}{ll}
\hline Protein* $^{*}$ & \% inhibition \\
\hline Alpha-cysteine protease inhibitor & 11 \\
Heavy chain HMWK $(64 \mathrm{kD})$ & 23 \\
Light chain HMWK $(56 \mathrm{kD})$ & $<2$ \\
High molecular weight kininogen & 93 \\
Alpha-2-macroglobulin & 29 \\
C1 inhibitor & $<2$ \\
Alpha-1-antitrypsin & $<2$
\end{tabular}

* Each protein was tested at a concentration of $200 \mathrm{nM}$, except for alpha-1-antitrypsin which was 3,200 nM. Incubation with platelet calpain was for $2 \mathrm{~min}$ at $25^{\circ} \mathrm{C}$. 


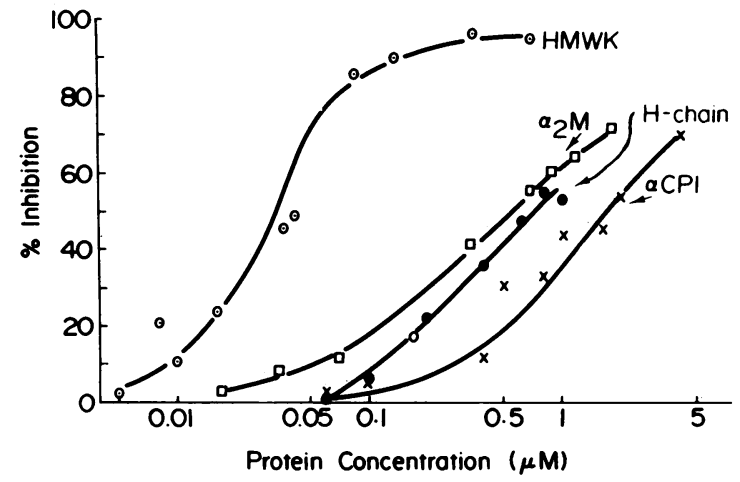

Figure 6. Comparison of purified HMWK, alpha-cysteine protease inhibitor and alpha-2-macroglobulin inhibition of platelet calpain. Purified platelet calpain in the presence of 2 mM EDTA was incubated with various concentrations of purified HMWK $(\odot)$; purified alpha-2-

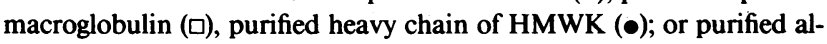
pha-cysteine protease inhibitor $(x)$ for $2 \mathrm{~min}$ at room temperature. Each point represents the mean of two to four experiments at each concentration with the purified protein.

presence of free $\mathrm{Ca}^{++}$in the incubation mixture. The $\mathrm{IC}_{50}$ for other purified plasma proteins was $500 \mathrm{nM}$ for alpha-2-macroglobulin, $1,700 \mathrm{nM}$ for alpha-cysteine proteinase inhibitor (LMWK), and $700 \mathrm{nM}$ for isolated heavy chain of HMWK (identical to the heavy chain of LMWK). In contrast to HMWK, the ability of alpha-cysteine protease inhibitor (LMWK) to inhibit platelet calpain was increased twofold by the presence of free $\mathrm{Ca}^{++}$in the incubation mixture. Because the $50 \%$ inhibitory concentration for HMWK resulted from only $5 \%$ of normal plasma concentration, and the $\mathrm{IC}_{50}$ for alpha-2-macroglobulin and heavy chain of HMWK were $15 \%$ and $30 \%$, respectively, of normal plasma concentrations, purified HMWK was predicted to be at least threefold as potent an inhibitor of platelet calpain than either purified alpha-2-macroglobulin or alpha-cysteine protease inhibitor (LMWK) in plasma.

Inhibition of platelet calpain by plasma. Further studies were performed to assess the effect of HMWK on platelet calpain in a plasma environment (Fig. 7). Because alpha-2-macroglobulin has been shown to inhibit platelet calpain (1), we diluted normal human plasma, total kininogen-deficient plasma (Williams plasma), and high molecular weight kininogen-deficient plasma (Fitzgerald plasma) so that their alpha-2-macroglobulin concentration was $1,000 \mathrm{nM}$ prior to studying each plasma's ability to inhibit the enzymatic activity of purified platelet calpain. At 1,000 $\mathrm{nM}$ alpha-2-macroglobulin concentration, normal plasma inhibited $97 \%$ of the caseinolytic activity of platelet calpain, whereas purified alpha-2-macroglobulin or Fitzgerald plasma at the same alpha-2-macroglobulin concentration inhibited only $72 \%$ of the activity of platelet calpain. Total kininogen-deficient plasma (Williams plasma) had a similar extent of platelet calpain inhibition $(66 \%)$. However, the $\mathrm{IC}_{50}$ of normal human plasma fell on the curve at a concentration of alpha-2-macroglobulin that was equivalent to $80 \mathrm{nM}$, whereas the $\mathrm{IC}_{50}$ of purified alpha2-macroglobulin, Fitzgerald plasma, and Williams plasma was between 300 and $600 \mathrm{nM}$ alpha-2-macroglobulin concentration. These findings indicated that normal plasma must contain an additional inhibitor of platelet calpain other than alpha-2-macroglobulin and alpha-cysteine protease inhibitor (LMWK). Further studies showed that treatment of normal plasma with 0.2

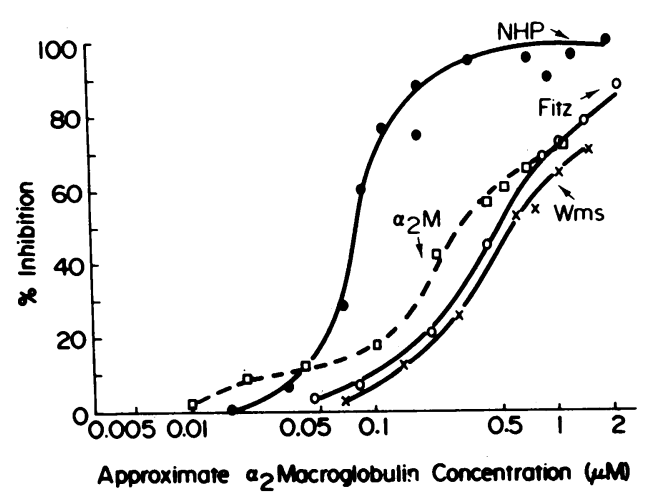

Figure 7. Comparison of plasma inhibition of platelet calpain. The approximate alpha-2-macroglobulin concentration in normal plasma, Fitzgerald plasma, and Williams plasma were determined by radial immunodiffusion and compared with purified alpha-2-macroglobulin. Dilutions of plasma were made such that the final approximate alpha2-macroglobulin concentration were the same. Each dilution of the plasma, as well as purified alpha-2-macroglobulin at a similar concentration, was incubated with the same amount of platelet calpain in the presence of $2 \mathrm{mM}$ EDTA for $2 \mathrm{~min}$ at $25^{\circ} \mathrm{C}$. Each point represents the mean of two to five experiments at each approximate alpha-2macroglobulin concentration with the purified protein or each plasma. (•) Normal human plasma; (), alpha-2-macroglobulin; (O), Fitzgerald plasma; and $(\times)$, Williams plasma.

M methylamine-a chemical inhibitor of alpha-2-macroglobulin (43)-did not change the $\mathrm{IC}_{50}$ of normal plasma on platelet calpain (data not shown). These findings indicated that alpha-2macroglobulin was not the major inhibitor of this enzyme in plasma. Because both Williams and Fitzgerald plasmas displayed weaker inhibitory activity towards platelet calpain than normal plasma, the additional inhibitor, therefore, appeared to be HMWK inasmuch as it was the common missing factor in both plasmas.

To test this hypothesis, the inhibitory capacity of normal human plasma for platelet calpain was directly compared with the inhibitory activity of purified HMWK (Fig. 8) under similar

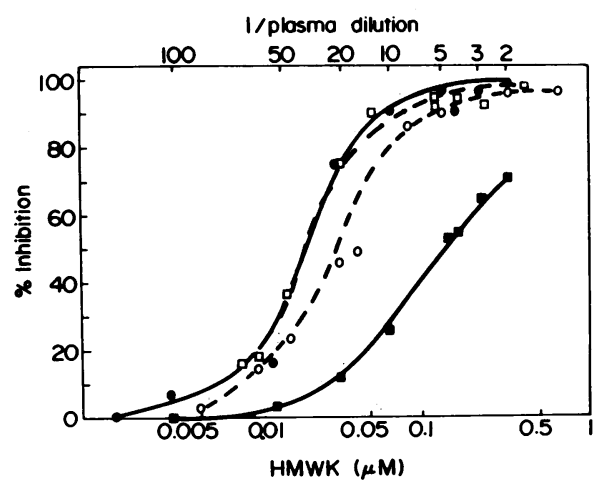

Figure 8. Effect of HMWK (purified or plasma) on inhibition of platelet calpain. The inhibition of platelet calpain by normal human plasma $(\bullet-\bullet)$, purified HMWK $(0---0)$, total kininogen-deficient plasma (Williams) reconstituted with $80 \mu \mathrm{g} / \mathrm{ml}(0.67 \mu \mathrm{M})$ of purified HMWK ( $\square---\square)$ and total kininogen-deficient plasma alone $(-)$ were compared. The concentration of purified HMWK $(\mu \mathrm{M})$ is on the bottom abscissa, and the plasma dilutions (normal and total kininogen-deficient) are labeled on the top abscissa. Each point represents the mean of two to five determinations. 
conditions. Purified HMWK was found to have an $\mathrm{IC}_{50}$ of 34 $\mathrm{nM}$ whereas normal human plasma had an $\mathrm{IC}_{50}$ of $23 \mathrm{nM}$, when calculated on the basis of its HMWK content. Likewise, when the $\mathrm{IC}_{\mathbf{s 0}_{0}}$ of normal plasma was compared with an equal dilution of total kininogen-deficient plasma, we found that it had sixfold greater inhibitory activity than total kininogen-deficient plasma (Fig. 8). Total kininogen-deficient plasma that was reconstituted with purified HMWK $(0.67 \mu \mathrm{M})$ displayed an $\mathrm{IC}_{50}$ of $20 \mathrm{nM}$, which was similar to what was observed with normal plasma. This correction of inhibitory activity contrasted with the minimal enhancement of inhibition when Fitzgerald plasma ( $1 \mu \mathrm{M}$ concentration LMWK) was reconstituted with purified heavy chain of HMWK (LMWK) (data not shown) to normal levels of 2.4 $\mu \mathrm{M}$ (16). The $\mathrm{IC}_{50}$ on platelet calpain increased about twofold, equivalent to about a 1:10 to 1:20 dilution of plasma although the total concentration of kininogen $(0.1-0.12 \mu \mathrm{M})$ contributing to the $\mathrm{IC}_{50}$ were similar. However, the $\mathrm{IC}_{50}$ of reconstituted Fitzgerald plasma with LMWK was twofold less by plasma dilution and threefold greater in kininogen concentration than the increased inhibitory capacity of reconstituted total kininogen-deficient plasma with $0.67 \mu \mathrm{M}$ purified HMWK alone (Fig. 8). This study indicated that LMWK was not the major plasma inhibitor of platelet calpain. Therefore, these combined studies suggested that HMWK is the major plasma inhibitor of platelet calpain.

\section{Discussion}

The finding (Fig. 1) that the plasma kininogens interact with the calcium-activated neutral protease (calpain) suggests a new functional role for the proteins of the contact phase of plasma proteolysis. In support of the findings of Ohkubo et al. (11) and Muller-Esterl et al. (13), both plasma HMWK and LMWK show complete identity with alpha-cysteine protease inhibitor on immunodiffusion (Fig. 2). We have extended these studies using immunoblotting (Fig. 3) to show that the heavy chains of both HMWK and LMWK also were immunochemically similar to alpha-cysteine protease. The lack of intensity of plasma LMWK on the immunoblot of normal plasma with the antikininogen antiserum was expected in that this antiserum was raised by injection of purified HMWK and is mostly directed to the light chain of HMWK. It was also not surprising that an alkylated and reduced heavy chain of HMWK that was produced by the kallikrein cleavage of whole HMWK only showed partial immunochemical identity to native alpha-cysteine protease inhibitor (LMWK) and purified HMWK (Fig. 2), because the unique light chain of each kininogen form is not present in the heavy chain preparation. However, the effects of alkylation and reduction on the heavy chain of HMWK were such that they did not interfere with the ability of the purified molecule to inactivate purified platelet calpain, similar to the native LMWK itself (Fig. 6).

The purified platelet calpain is similar to what has been previously reported $(5,6)$, having two subunits, 80 and $30 \mathrm{kD}$, similar to that described in rat kidney (44). Unlike the findings of Sakon et al. (4), we found only one form of platelet calpain that responded to $\mathrm{mM}$ concentrations of free calcium, which would classify the enzyme as a calpain II (44). Our finding of a single platelet calcium-activated protease, which is best activated by millimolar concentrations of free calcium, are supported by the findings of Yoshida et al. (5) and Truglia and Stracher (6). However, there is a difference in the calculated absolute con- centration of free calcium needed to activate platelet calpain in our studies, when compared to previous studies (5). We found optimal activation at $0.5 \mathrm{mM}$ free $\mathrm{Ca}^{++}$, contrasting with the optimum of $1 \mathrm{mM}$ free $\mathrm{Ca}^{++}$found in the study of Yoshida et al. (5). This difference can be explained by the methodology used to calculate the free $\mathrm{Ca}^{++}$as well as the buffer, $\mathrm{pH}$, and temperature whereby the study was performed. In agreement with our finding, however, Kitahara et al. (34) found a calpain II in porcine kidney with maximal activity at a free $\mathrm{Ca}^{++}$concentration of $0.5 \mathrm{mM}$. Furthermore, similar to the observations of Yoshida et al. (5), we found that the purified enzyme autodigests when exposed to calcium. In our experiments, the addition of 2 mM EDTA to an incubation mixture prevented enzyme self-destruction during 0-10-min incubations.

The finding that HMWK is another plasma protein that can inhibit calpains indicates a third plasma protein, along with alpha-2-macroglobulin and LMWK, that could regulate these tissue-derived cytosolic enzymes (Figs. 6-8). This observation was predicted, because the heavy chain of HMWK and LMWK are identical in amino acid composition $(15,45)$ as well as immunochemical reactivity (41). However, an unexpected finding was that HMWK, on a molar basis, was a more potent inhibitor of platelet calpain than either alpha-2-macroglobulin, alpha-cysteine protease inhibitor (LMWK) or isolated heavy chain of HMWK, under the conditions employed (Fig. 6). Unlike some cysteine protease inhibitors $(27,28)$, free calcium was found to exert no influence on the ability of HMWK to inhibit platelet calpain. This finding suggests that the native conformation of HMWK contributes to its activity as an inhibitor.

The results from Figs. 7 and 8 indicate that HMWK is an important plasma inhibitor of platelet calpain. In experiments where normal plasma and plasmas congenitally deficient in total kininogen or HMWK were compared, we observed that plasma containing HMWK exhibited the greatest degree of inhibition of platelet calpain (Fig. 7). The finding that Fitzgerald plasma (plasma deficient in only HMWK) displayed greater inhibition of platelet calpain at low dilutions than either purified alpha-2macroglobulin alone or Williams plasma (total kininogen-deficient plasma) is not surprising, because Fitzgerald plasma does contain some LMWK (Fig. 7). However, at higher dilutions, the inhibitory contribution of LMWK is lost because the concentration of LMWK in this plasma is subnormal at $63 \mu \mathrm{g} / \mathrm{ml}(0.98$ $\mu \mathrm{M})$. Although reconstitution of Fitzgerald plasma with purified heavy chain of HMWK to levels of LMWK in normal plasma $(2.4 \mu \mathrm{M})$ led to a twofold increase in the calpain inhibitory capacity of this plasma, full inhibitory activity was not attained (Figs. 7 and 8). Finally, in reconstitution experiments, where purified HMWK was added to total kininogen-deficient plasma to achieve a normal level $(0.67 \mu \mathrm{M})$, we observed inhibition of platelet calpain which was virtually identical to that obtained with normal plasma (Fig. 8). These combined studies indicate that HMWK is the major plasma inhibitor of platelet calpain, accounting for $\sim 80-90 \%$ of the platelet calpain inhibitory capacity of plasma. Preliminary kinetic studies indicate that HMWK is a tight noncompetitive inhibitor of platelet calpain with an apparent $K_{\mathrm{i}}$ of $5 \mathrm{nM}$.

The structural basis by which HMWK [plasma concentration, $0.67 \mu \mathrm{M}(18)]$ supercedes plasma alpha-2-macroglobulin [plasma concentration, $3.4 \mu \mathrm{M}$ (17)] and LMWK [plasma concentration, $2.4 \mu \mathrm{M}(16)$ ] as an inhibitor of platelet calpain is not known. Preliminary studies from this laboratory indicate that HMWK is also a substrate for platelet calpain (10). Platelet cal- 
pain can proteolyze HMWK into cleavage products of smaller mass and can increase the surface-mediated coagulant activity of the molecule 35-fold (10). Many protease inhibitors are also substrates for the enzymes they inhibit (46). These findings indicate that platelet calpain, in addition to its interaction with the heavy chain of HMWK, may alter the light chain of HMWK, the portion of the HMWK molecule which contains the coagulant activity of the molecule $(12,45,47)$. Finally, although calcium is needed for optimal inhibition of small active sitedirected inhibitors $(27,28)$ and LMWK, but not for the inhibitory activity of HMWK, the additional bulk of the light chain may exert steric effects to account for increased inhibition of HMWK compared to that of LMWK.

The finding that plasma kininogens are important regulators of tissue enzymes indicates a new function for the kininogens. However, because the calpains are cytosolic proteins, one must consider how these two differently located proteins may communicate under physiologic conditions. It is possible that the important form of kininogen that may regulate platelet calpain is that which is located within platelets (18). Because platelet HMWK is mostly a granule protein $(10,18)$ and platelet calpain is cytosolic, these proteins might interact when platelets are activated, at which time platelet granule contents might communicate with platelet cytosol. Both platelet and plasma kininogens could be important inhibitors of cytosolic platelet calpain subsequent to platelet cytolytic injury by mechanical trauma or complement activation. This latter notion is in accord with our current hypothesis (10) of the role of HMWK and other proteins of the contact phase of plasma proteolysis as mediators of defense reactions to injury and inflammation.

\section{Acknowledgments}

We would like to express our appreciation to Dr. A. D. Purdon for his aid in the calculations of free $\mathrm{Ca}^{++}$concentrations and to Ms. Pat Pileggi for her expert secretarial assistance.

This study was supported in part by a National Heart, Lung and Blood Institute clinical investigator award (HL-00694) (Dr. Schmaier), an American Heart Association grant-in-aid (81725) (Dr. Schmaier), an American Heart Association Allegheny Mountain Pennsylvania Chapter grant-in-aid (Dr. Schmaier), a grant from the National Institutes of Health (HL24365) (Dr. Colman), a grant from The Council of Tobacco Research (1420) (Dr. Colman), and the Ben Franklin Partnership.

\section{References}

1. Waxman, L. 1981. Calcium-activated proteases in mammalian tissues. Methods Enzymol. 80:664-680.

2. Murachi, T., K. Tanaka, M. Hatanaka, and T. Murakami. 1981. Intracellular $\mathrm{Ca}^{2+}$-dependent protease (calpain) and its high molecular weight endogenous inhibitor (calpastatin). Adv. Enzyme Regul. 19:407424.

3. Philips, D. R., and M. Jakabova. 1977. $\mathrm{Ca}^{++}$-dependent protease in human platelets. J. Biol. Chem. 252:5602-5605.

4. Sakon, M., J.-I. Kambayashi, H. Ohno, and G. Kosaki. 1981. Two forms of $\mathrm{Ca}^{++}$-activated neutral protease in platelets. Thromb. Res. 24: 207-214.

5. Yoshida, N., B. Weksler, and R. Nachman. 1983. Purification of human platelet calcium-activated protease: effect on platelet and endothelial function. J. Biol. Chem. 258:7168-7174.

6. Truglia, J. A., and A. Stracher. 1981. Purification and characterization of a calcium dependent sulfhydryl protease from human platelets. Biochem. Biophys. Res. Commun. 100:814-822.
7. Kunicki, T. J., R. R. Montgomery, and J. Schullek. 1985. Cleavage of human von Willebrand factor by platelet calcium-activated protease. Blood. 65:352-356.

8. Kunicki, T. J., M. W. Mosesson, and D. Pidard. 1984. Fibrinogen cleavage by human platelet calcium-activated protease. Thromb. Res. 35:169-182.

9. Tracy, P. B., M. E. Nesheim, and K. G. Mann. 1983. Proteolytic alteration of factor Va bound to platelets. J. Biol. Chem. 258:662-669.

10. Schmaier, A. H., P. M. Smith, A. D. Purdon, J. G. White, and R. W. Colman. 1986. High molecular weight kininogen: localization in the unstimulated and activated platelet and activation by a platelet calpain(s). Blood. 67:119-130.

11. Ohkubo, I., K. Kurachi, T. Takasawa, H. Shiokawa, and M. Sasaki. 1984. Isolation of human cDNA for alpha-2-thiol protease inhibitor and its identity with low molecular weight kininogen. Biochemistry. 23:3891-3899.

12. Gounaris, A. D., M. A. Brown, and A. J. Barrett. 1984. Human plasma alpha cysteine proteinase inhibitor: purification by affinity chromatography, characterization and isolation of an active fragment. Biochem. J. 221:445-452.

13. Muller-Esterl, W., H. Fritz, W. Machleidt, A. Ritonja, J. Brzin, M. Kotnik, V. Turk, J. Kellermann, and F. Lottspeich. 1985. Human plasma kininogens are identical with alpha-cysteine proteinase inhibitors: evidence from immunological, enzymological and sequence data. FEBS (Fed. Eur. Biochem. Soc.) Lett. 182:310-314.

14. Sueyoshi, T., K. Enjyoji, T. Shimada, H. Kato, S. Iwanaga, Y. Bando, E. Kominami, and N. Katunuma. 1985. A new function of kininogens as thiol-proteinase inhibitors: inhibition of papain and cathepsins $\mathrm{B}, \mathrm{H}$ and $\mathrm{L}$ by bovine, rat and human plasma kininogens. FEBS (Fed. Eur. Biochem. Soc.) Lett. 182:193-195.

15. Kitamura, N., Y. Takagaki, S. Furuto, T. Tanaka, H. Nawa, and S. Nakanishi. 1983. A single gene for bovine high molecular weight and lower molecular weight kininogens. Nature (Lond.). 305:545-549.

16. Muller-Esterl, W., M. Vohle-Timmermann, B. Boos, and B. Dittman. 1982. Purification and properties of human low molecular weight kininogen. Biochim. Biophys. Acta. 706:145-152.

17. Pixley, R. A., M. Schapira, and R. W. Colman. 1985. The regulation of human factor XII by plasma proteinase inhibitors. J. Biol. Chem. 260:1723-1729.

18. Schmaier, A. H., A. Zuckerberg, C. Silverman, J. Kuchibhotla, G. P. Tuszynski, and R. W. Colman. 1983. High molecular weight kininogen: a secreted platelet protein. J. Clin. Invest. 71:1477-1489.

19. Proud, D., J. V. Pierce, and J. J. Pisano. 1980. Radioimmunoassay of human high molecular weight kininogen in normal and deficient plasma. J. Lab. Clin. Med. 95:563-574.

20. Schmaier, A. H., W. Claypool, and R. W. Colman. 1980. Crotalocytin: recognition and purification of a timber rattlesnake platelet aggregating protein. Blood. 56:1013-1019.

21. Mustard, J. F., D. W. Perry, N. H. Ardlie, and M. A. Packham. 1972. Preparation of suspensions of washed platelets from humans. $\mathrm{Br}$. J. Haematol. 22:193-204.

22. Molnar, J., and L. Lorand. 1961. Studies of apyrases. Arch. Biochem. Biophys. 93:353-363.

23. Timmons, S., and J. Hawiger. 1978. Separation of human platelets from plasma proteins including factor VIII by a combined albumin gradient-gel filtration method using Hepes buffer. Thromb. Res. 12:297306.

24. Laemmli, U. K. 1970. Cleavage of structural proteins during the assembly of the head of bacteriophage $T_{4}$. Nature (Lond.). 227:680-685.

25. Waxman, L., and E. Krebs. 1978. Identification of two protease inhibitors from bovine cardiac muscle. J. Biol. Chem. 253:5888-5891.

26. De Martino, B., and D. Blumenthal. 1982. Identification and partial purification of a factor that stimulates calcium-dependent proteases. Biochemistry 21:4297-4303.

27. Suzuki, K., S. Tsuji, and S. Ishiura. 1981. Effect of $\mathrm{Ca}^{2+}$ on the inhibition of calcium-activated neutral protease by leupeptin, antipain and epoxysuccinate derivatives. FEBS (Fed. Eur. Biochem. Soc.) Lett. 136:119-122. 
28. Suzuki, K. 1983. Reaction of calcium-activated neutral protease (CANP) with epoxysuccinyl derivative (E64c) and Iodoacetic acid. $J$. Biochem. 93:1305-1312.

29. Tallarida, R. J., and R. B. Murray. 1981. Manual of Pharmacologic Calculations with Computer Programs. Springer-Verlag, New York. 37-39.

30. Kerbiriou, D. M., and J. H. Griffin. 1979. Human high molecular weight kininogen: studies of the structure-function relationships and of proteolysis of the molecule occurring during contact activation of plasma. J. Biol. Chem. 254:12020:12027.

31. Schmaier, A. H., P. M. Smith, and R. W. Colman. 1985. Platelet Cl INH. A secreted alpha-granule protein. J. Clin. Invest. 75:242-250.

32. Glaser, C. B., L. Karic, and R. Fallat. 1975. Isolation and characterization of alpha-1-antitrypsin from the Cohn Fraction IV-I of human plasma. Prep. Biochem. 5:333-348.

33. Schmaier, A. H., E. Gustafson, S. Idell, and R. W. Colman. 1984. Plasma prekallikrein assay: reversible inhibition of $\mathrm{Cl}$ inhibitor by chloroform and its use in measuring prekallikrein in different mammalian species. J. Lab. Clin. Med. 104:882-892.

34. Kitahara, A., T. Sasaki, T. Kikuchi, N. Yumoto, N. Yoshimura, M. Hatanaka, and T. Murachi. 1984. Large-scale purification of porcine calpain I and Calpain II and comparison of proteolytic fragments of their subunits. J. Biochem. 95:1759-1766.

35. Davis, B. J. 1964. Disc electrophoresis. II. Method and application to human serum proteins. Ann. NY Acad. Sci. 121:404-427.

36. Wolf, H. U. 1973. Divalent metal ion buffers with low pH-sensitivity. Experientia 29:241-249.

37. Perrin, D., and I. Sayce. 1967. Computer calculation of equilibrium concentrations in mixtures of metal ions and complexing species. Talanta. 14:833-842.

38. Bradford, M. M. 1976. Rapid and sensitive method for the quan- tification of microgram quantities of protein utilizing the principle of protein-dye binding. Anal. Biochem. 72:248-254.

39. Lowry, O. H., N. J. Rosebrough, A. L. Farr, and R. J. Randall. 1951. Protein measurement with Folin phenol reagent. J. Biol. Chem. 193:265-275.

40. Ross, E., and G. Schatz. 1973. Assay of proteins in the presence of high concentrations of sulfhydryl compounds. Anal. Biochem. 54: 304-306.

41. Schmaier, A. H., L. D. Silver, A. L. Adams, G. C. Fischer, P. C. Munoz, L. Vroman, and R. W. Colman. 1984. The effect of high molecular weight kininogen on surface-adsorbed fibrinogen. Thromb. Res. 33:51-67.

42. Towbin, H., T. Staehelin, and J. Gordon. 1979. Electrophoretic transfer of proteins from polyacrylamide gels to nitrocellulose sheets: procedure and some applications. Proc. Natl. Acad. Sci. USA. 76:13501354.

43. Schapira, M., L. D. Silver, C. F. Scott, and R. W. Colman. 1982. New and rapid functional assay for $\mathrm{Cl}$ inhibitor in human plasma. Blood. 59:719-724.

44. Yoshimura, N., T. Kikuchi, T. Sasaki, A. Kitahara, M. Hatanaka, and T. Murachi. 1983. Two distinct $\mathrm{Ca}^{2+}$ proteases (calpain I and calpain II) purified concurrently by the same method from rat kidney. J. Biol. Chem. 258:8883-8889.

45. Nawa, H., N. Kitamura, T. Hirose, M. Asai, S. Inayama, and S. Nakanishi. 1983. Primary structure of bovine liver low molecular weight kininogen precursors and their two mRNA's. Proc. Natl. Acad. Sci. USA. 80:90-94.

46. Carrell, R., and J. Travis. 1985. Alpha-1-antitrypsin and serpins: variation and countervariation. Trends Biochem. Sci. 10:20-24.

47. Thompson, R. E., R. Mandle, Jr., and A. P. Kaplan. 1978. Characterization of human high molecular weight kininogen. J. Exp. Med. 147:488-499. 